\title{
The Urban Working Class and Social Protest in Latin America
}

\section{Peter Winn}

\author{
Research Institute on International Change
}

Columbia University

Recent events in Latin America have underscored the political importance of the urban working class, whether as protagonists of social protest or as targets of military repression. At the same time, the development of promising new approaches to the study of urban workers in Europe and the United States has transformed a neglected subject into a frontier of scholarship, an example which has begun to inspire a new generation of Latin Americanists.

This conjunction of political concern and scholarly opportunity prompted a workshop on "The Urban Working Class and Social Protest in Latin America" at the Woodrow Wilson Center in Washington, D.C., on November 30 and December 1,1978. The workshop was convened at the intiative of Eugene Sofer and Alexander Wilde of the Center. Eighteen specialists from the United States, Argentina, Brazil, Chile, Peru, Cuba, and Italy participated in the meeting. Most of them contributed papers, which were circulated in advance of the gathering and which will be available from the Center as "Working Papers."

The workshop's underlying hope was that bringing together some of the leading students of the urban working class in Latin America with representative practitioners of the new labor studies in Europe and the United States would facilitate an assessment of the state of the field, an exploration of the most promising new approaches, and a definition of the most important questions for future research. Although the colloquium did not fulfill all of these expectations, it gave promise of important new developments in the field.

A mixture of the old and the new in labor studies, the workshop itself exemplified the Janus-headed character of contemporary scholarship. Although several examples of new approaches were presented, most of the papers were limited to the traditional focus on unions, leaders, and parties. The workshop prospectus, prepared by Sofer, had encouraged participants to abandon this older perspective in favor of the concern with culture and consciousness viewed from below that typifies the new labor studies in Europe and the United States. It was striking how difficult this reorientation proved to be in practice. In some cases, the spirit was willing but the pull of tradition was 
too strong or the research base for an alternate vision too weak. Other participants infused essentially traditional papers with some of the new concerns. Several contributors, however, rejected the methodological manifesto with which Sofer convened the workshop and reaffirmed the validity and the importance of the old questions and approaches.

Even these traditionalists, however, informed their presentations with analytical concerns that carried them well beyond the chronicles, taxonomies, and political polemics of the past, frequently reflecting instead the themes that have recently dominated Latin American studies generally. The interest in corporatism and the role of the state was reflected in several papers, as was the Gramscian preoccupation with the problem of working-class leadership and the debate over the linkages of Latin American labor movements with populist, social democratic, and Marxist politics. Significantly, although the perspective of dependency theory underlay the comments of many participants, dependencia was conspicuous by its absence from the formal presentations.

Much of the early discussion was devoted to defining the workshop's concerns more precisely. There were appeals to study the non-union majority of the urban workforce and unorthodox forms of association, as well as defenses of the focus on organized labor as the sector of the working class which provided its political leadership. There was also some provocative, if tentative, discussion of the utility of techniques of analysis of crowds and popular culture, which historians of Europe and the United States have applied to early industrialization, for the study of "marginal" urban populations and their interaction with organized workers. It was evident that systematic research was needed even to learn whether those two groups of urban dwellers have been different people or interlocked through families and life cycles during the recent epoch, when corporatist legislation and rapid urbanization have made both so visible.

Several papers dealt with questions of class formation, culture, consciousness, and social protest. The variety of disciplinary, ideological and national perspectives brought to bear on these subjects made the discussion fruitful. Inevitably the workshop had to grapple with the questions of class and class consciousness, often with more conflict than consensus about their definition, measurement or significance. Louis Goodman's survey of the attitudes of Chilean workers made him question the utility of the concept of class; several other presentations made class the touchstone of their analyses. In the end, participants agreed on the need to study class dynamically, as expressed historically in conflict with other social strata. The working class, stressed Gianfranco Pasquino, was a political project as well as an objective category, an act of continuous creation carried out in the face of opposing efforts of other classes.

Consciousness proved equally controversial a subject. For example, several papers clashed directly with each other about its character in Chile 
during the past decade. Throughout these discussions a methodological debate kept surfacing between those who viewed consciousness as an "attitude," best captured by the survey techniques of the sociologist at a single point in time, and those who understood by consciousness a "deep world view," best expressed in behavior and best studied in its ebb and flow through the participant-observer approach of the anthropologist. Samuel Valenzuela suggested that the differences between the two sides also reflected the eras under investigation- "normal" versus "revolutionary" epochs. The explicit airing of this methodological conflict was one of the most significant achievements of the workshop. Moreover, if there was little consensus on the character of working-class consciousness, there was general agreement on its importance as the link between popular culture and social protest.

Although there were fewer papers on working-class culture than anticipated and only one (June Nash's paper on Bolivian miners) which really exemplified the view "from below" of the new labor studies, the question of culture figured in several of the presentations. Nash's study highlighted the adaptation of pre-industrial cultural forms in the making of a working-class culture, the ways in which the community maintains that culture, and the role of women in transmitting it from generation to generation. Her insights evoked a general agreement on the need to study the "cultural baggage" which rural migrants have brought with them to Latin American cities and mining towns as a means of understanding working-class consciousness and organization.

Several participants argued for an approach to the study of culture which takes into consideration the formation of distinct sub-cultures, whether based on ethnicity, religion, income, skill, residence, or job security. Torcuato Di Tella underscored the hegemonic influence of the dominant culture upon that of the working class and the contrast between the world-view of the militants and that of the social milieu from which they have sprung. On the other hand, Peter Winn stressed the existence of an autonomous working-class culture of resistance, which asserts itself openly in times of class conflict.

Social protest was another central theme of the workshop, though the success of the papers in viewing it from below was limited. There were suggestive accounts (by Peter Klarén and Denis Sulmont) of popular protests in Lima during the second decade of this century and during the past two decades, as well as José Moisés' thoughtful analysis of the 1953 "strike of the 300,000 " in Sao Paulo. The papers presented, however, studied a relatively restricted range of social protests, leading David Montgomery to ask if there had never been a food riot, rent strike, or workers' control struggle in Latin America.

Equally important was the discussion of the causes of social protest. Several participants underscored the impact of economic crises on workers whose low real wages left little room for further sacrifice. Goodman, on the other hand, stressed the impact of dashed rising expectations in sparking social protest, while Winn argued that the perception of a political opening could 
also elicit powerful surges of working-class struggles, and even generate a revolution from below.

Revolution, the ultimate form of social protest, was the subject of several papers, with varying concerns and conclusions. Henry Landsberger denied that Chilean workers had manifested a revolutionary consciousness during the rise of the Popular Unity movement, while Juan Espinoza discussed their revolutionary role in effectively asserting workers' self-management in industry. Lourdes Casal, on the other hand, analyzed the pre-revolutionary role of Cuban workers, arguing that their struggles, awareness, and organization were preconditions for the revolution of 1959 and stressing that revolutionary consciousness was a consequence, rather than a cause, of participation in a revolution.

Throughout the sessions there was an understandable tendency to generalize from the experiences of the nation that participants knew best, but one of the positive features of the workshop was the level of comparative analysis it stimulated, both of different Latin American countries and between them and apposite European cases. Moreover, while most of the papers studied the recent past, there were several which focused on earlier epochs and argued persuasively for the importance of understanding the formative period and early struggles of Latin American working classes, which in many cases shaped the patterns of elite responses, state policies, and working-class organizations that have endured to this day.

Inevitably a workshop held at this juncture in the development of the field of study was more suggestive than definitive. In the public symposium which closed the workshop, Peter Winn summarized its results, underscoring the limitations of knowledge, methodology and understanding that it had revealed and the need for more (and more varied) research. He called for a moratorium on global generalizations about "the Latin American working class" until the monographic research and cross-national comparisons upon which such generalizatons should be based had been undertaken. Thomas Skidmore urged Latin Americanists to learn from anthropologists and the new social historians in their approaches to these questions, without losing sight of the interaction between the working class and the state. David Montgomery underscored the importance of studying the workplace and economic contexts of labor struggles. Gianfranco Pasquino focused attention on the need for more sophisticated research on working-class formation, consciousness, culture, and organization, and in particular upon the ways in which class consciousness and organization build upon each other. If the comments of Montgomery and Pasquino underscored the value of the comparative perspective that they had brought to the workshop, the opening of a dialogue between students of the urban working class in Latin America and those who have studied its European and United States counterparts was one of the session's signal achievements. Hopefully it was but the beginning of a continuing and fruitful interchange. 